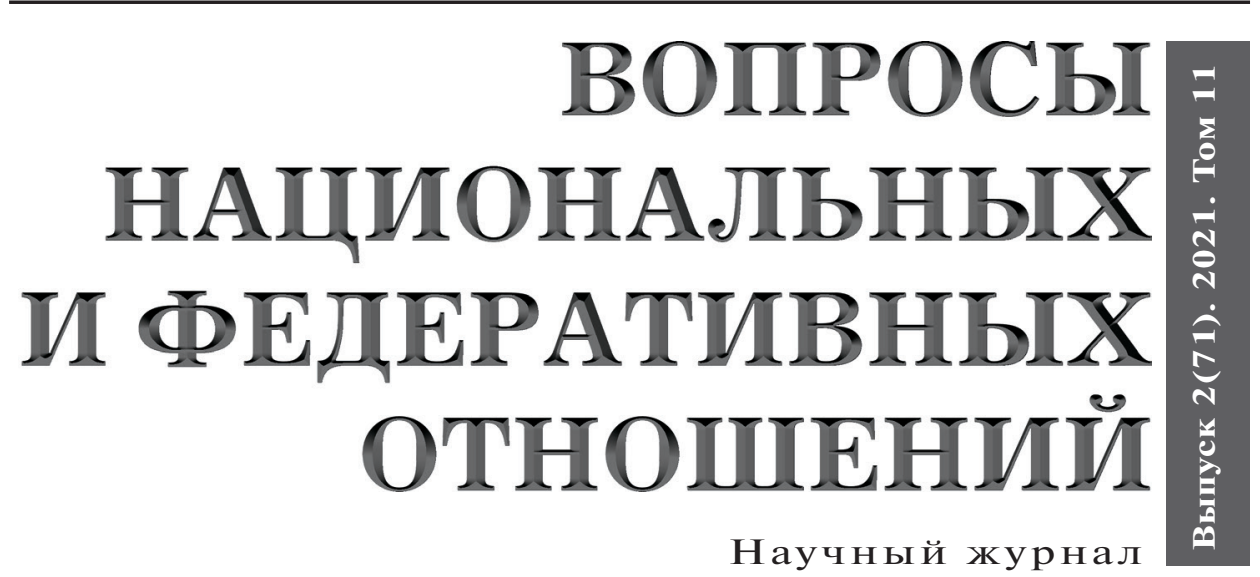

Журнал «Вопросы национальных и федеративных отношений» включен в перечень рецензируемых научных изданий ВАК, в которых должны быть опубликованы основные научные результаты на соискание ученой степени кандидата наук, на соискание ученой степени доктора наук по политическим и историческим наукам 


\section{Научный журнал}

Вячеслав Александрович МИХАЙЛОВ

Рамазан Гаджимурадович АБДУЛАТИПОВ

\section{Любовь Федоровна БОЛТЕНКОВА \\ Владимир Иванович ВАСИЛЕНКО}

Владимир Александрович ВОЛОх

Вадим Витальевич

ГАЙДУК

Леокадия Михайловна ДРОБИЖЕВА

\section{Владимир Юрьевич} ЗОРИН

Раушан Мусахановна КАНАПЬЯНОВА

\section{В. Микаэль} КАССАЕ НЫГУСИЕ

Геннадий Яковлевич КОЗЛОВ

Игорь Георгиевич КОСИКОВ

Николай Павлович МЕДВЕДЕВ

Марина Николаевна МОСЕЙКИНА

Александр Данилович НАЗАРОВ

Дарья Вячеславовна ПЕРКОВА

Александр Васильевич ПОНЕДЕЛКОВ

Дмитрий Егорович СЛИЗОВСКИЙ

Шукран Саидовна СУЛЕЙМАНОВА

Жибек Сапарбековна СЫЗДЫкОВА
Председатель Совета, д.и.н., профессор, зав. кафедрой национальных и федеративных отношений РАНХ и ГС при Президенте РФ

\section{Редакционный Совет}

д.ф.н., постоянный представитель Российской Федерации при Организации Исламского сотрудничества

д.ю.н., профессор РАНХ и ГС при Президенте РФ

д.п.н., профессор Российской академии народного хозяйства и государственной службы при Президенте РФ

д.П.н., профессор Государственного университета управления

д.п.н., профессор Башкирского государственного университета

д.и.н., руководитель Центра исследования межнациональных отношений Института Социологии ФНИСЦ РАН

д.п.н., руководитель Центра по научному взаимодействию с общественными организациями, СМИ и органами государственной власти ИЭА РАН

д.п.н., профессор кафедры международного культурного сотрудничества МГИК

д.и.н., профессор кафедры теории и истории международных отношений Российского университета дружбы народов

д.и.н., профессор Рязанского государственного университета им. С.А. Есенина

д.и.н., главный научный сотрудник Института этнологии и антропологии РАН

д.п.н., профессор Российского университета дружбы народов

д.и.н. профессор, заведующая кафедрой истории России Российского университета дружбы народов

д.и.н., профессор, зам. руководителя кафедры по научной работе Московского авиационного института к.п.н., ответственный редактор

д.п.н., профессор, заведующий кафедрой политологии и этнополитики Южно-Российского института управления - филиал РАНХ и ГС при Президенте РФ

д.и.н., профессор кафедры истории России Российского университета дружбы народов

д.п.н., профессор Российской академии народного хозяйства и государственной службы при Президенте РФ

д.и.н., профессор, заведующая кафедрой стран Центральной Азии и Кавказа Института стран Азии и Африки Московского государственного университета имени М. В. Ломоносова, заместитель главного редактора журнала

Редакционная коллегия

Главный редактор - СУЛЕЙМАНОВА Ш.С., д.п.н., профессор РАНХиГС

Члены ред. коллегии:

Волох В.А. (зам. главного редактора),

Сыздыкова Ж.С. (зам. главного редактора),

Перкова Д.В. (ответственный редактор)

Болтенкова Л.Ф., Дробижева Л.А. Слизовский Д.Е.

\author{
УЧРЕЖДЕН \\ ООО «Издательство \\ «Наука сегодня»
}

\section{ЖУРНАЛ ВКЛЮЧЕН \\ В ПЕРЕЧЕНЬ ВАК РФ}

Журнал зарегистрирован Федеральной службой по надзору в сфере массовых коммуникаций,

связи и охраны культурного наследия

Регистрационный номер

ПИ № ФС77-47487

от 25 ноября 2011 г.

Журнал издается ежемесячно

Журнал включен в базу РИНЦ

(Российский индекс научного цитирования)

Включен в каталог

Ulrich's Periodicals Directory

Пятилетний импакт-фактор журнала: 1,006

Адрес редакции:

115598 , г. Москва, ул. Загорьевская, д. 10, корп. 4, цокольный этаж, помещение I, комната 7-1, офис 4

Тел.: (910) 463-53-42

www.etnopolitolog.ru

E-mail: etnopolitolog@yandex.ru

Мнение авторов может не совпадать с мнением редакции.

При перепечатке ссылка на журнал обязательна.

Научные статьи, публикуемые в журнале подлежат обязательному рецензированию.

Ответственный редактор Перкова Д.В.

Компьютерная верстка Анциферова А.С.

Подписано в печать 25.02.2021.

Формат 60×84/8. Объем 24,3. Печать офсетная. Тираж - 1000 экз. (1-й завод - 500 экз.) Заказ № 000

Отпечатано в типографии ООО «Белый ветер»

115054, г. Москва, ул. Щипок, 28

Тел.: (495) 651-84-56 
ISSN 2226-8596 (print)

12 выпусков в год и

2 выпуска в год переводной (англ.) версии

Языки: русский, английский

http://etnopolitolog

Входит в перечень рецензируемых научных изданий ВАК РФ

Включен в каталог периодических изданий Ульрих (Ulrich’s Periodicals Directory: http://www.ulrichsweb.com) Материалы журнала размещаются на платформе РИНЦ Российской научной электронной библиотеки, Electronic Journals

Library Cyberleninka

Подписной индекс издания в каталоге агентства Роспечать 70114

\section{Цели и тематика}

Журнал ВОПРОСЫ НАЦИОНАЛЬНЫХ И ФЕДЕРАТИВНЫХ ОТНОШЕНИЙ - периодическое международное рецензируемое на ᄀучное издание в области политических исследований. Журнал является международным как по составу редакционного совета и редколлегии, так и по авторам и тематике публикаций.

Научный журнал издается с 2011 года в издательстве «Наука сегодня». С 2018 года издается переводная (англ.) версия журнала. С момента своего создания, журнал ориентировался на высокие научные и этические стандарта и сегодня является одним из ведущих политологических журналов России.

Цель журнала - способствовать научному обмену и сотрудничеству между российскими и зарубежными политологами

Журнал предназначен для публикации результатов фундаментальных и прикладных научных исследований. Тематическая направленность журнала отражается в следующих постоянных рубриках: «Отечественная история, этнология и этнография», «История международных отношений и мировой политики», «История и философия политики», «Политические институты, процессы и технологии», «Политическая культура, этнополитика и идеологии», «Политические проблемы международных отношений и глобализации».

Формат публикаций: научные статьи, обзорные научные материалы, материалы круглых столов, научные рецензии, научные сообщения, посвященные исследовательским проблемам в сфере политики и политологии.

В своей деятельности редакционный совет и редколлегия журнала руководствуется принципами, определяемыми ВАК России для научных журналов, в том числе: наличие института рецензирования для экспертной оценки качества научных статей; информационная открытость издания; наличие и соблюдение правил и этических стандартов представления рукописей авторами.

Целевой аудиторией журнала являются российские и зарубежные специалисты-политологи, а также аспиранты и магистры, обучающиеся по направлениям политология, государственное и муниципальное управление и международные отношения.

Журнал строго придерживается международных стандартов публикационной этики, обозначенных в документе СОРЕ (Committee on Publication Ethics) http://publicationethics.org

Полные сведения о журнале и его редакционной политике, требования о подготовке и публикации статей, архив (выпуски с 2011 года) и дополнительная информация размещена на сайте: http://etnopolitolog.ru

Электронный адрес: etnopolitolog@yandex.ru

ISSN 2226-8596 (print)

12 issues a year plus 2 issues a year of the translated (eng.) version Languages: Russian and English http://etnopolitolog

Included in the list of peer-reviewed scientific publications of the Higher Attestation Commission of the Russian Federation Included in the Ulrich's Periodicals Directory Materials of the journal are placed on the RSCI platform of the Russian scientific electronic library - Electronic Journals Library Cyberleninka Subscription index of the journal in the Rospechat Agency catalogue is: 70114

\section{Objectives and themes}

Academic journal "Issues of National and Federative Relations" is an international peer-reviewed scientific periodical in the field of political studies. The journal has an international character because of the composition of its Editorial Board, its editors, its contributing authors and topics of its publications.

The scientific journal is published since 2011 at the "Publishing House "Science Today". Translated (eng.) version of the journal is published since 2018. Since its inception, the journal was guided by high scientific and ethical standards and today it is one of the leading political science journals in Russia.

The purpose of the journal is to promote scientific exchange and cooperation between Russian and foreign political scientists.

The journal is intended for the publication of the results of fundamental and applied scientific research. Thematic focus of the journal is reflected in the following permanent headings: "Domestic history, ethnology and ethnography", "History of international relations and world politics", "History and philosophy of politics", "Political institutions, processes and technologies", "Political culture, ethnopolitics and ideologies", "Political problems of international relations and globalization."

Format of publications: scientific articles, reviews, scientific materials, materials of round tables, scientific reviews, scientific reports devoted to research problems in the field of politics and political science.

The Editorial Board and the editors of the journal in their activities are guided by the principles defined by VAK of Russia for scientific journals, including: presence of the institute of peer review for the expert quality assessment of scientific articles; information openness of the publications; availability and compliance with the rules and ethical standards for the submission of manuscripts by the authors.

The target audience of the journal is Russian and foreign specialists-political scientists, as well as graduate students and masters in the fields of political science, state and municipal management and international relations.

The journal strictly adheres to the international publishing standards and publication ethics identified in the COPE (COmmittee on Publication Ethics) document. http://publicationethics.org.

Full details of the journal and its editorial policy, requirements to the preparation and publication of articles, archive (issues since 2011) and additional information are available on the website: http://etnopolitolog.ru

E-mail address: etnopolitolog@yandex.ru 
ОТЕЧЕСТВЕННАЯ ИСТОРИЯ, ЭТНОЛОГИЯ И ЭТНОГРАФИЯ

Костриков С.П. Оценка событий 1903 г. в Македонии

и Старой Сербии приверженцами идеи славянского единства

в русском общественном мнении (На примере анализа

материалов «Известий С.-Петербургского Славянского

Благотворительного Общества»)

Бориснёв С.В., Вититнев С.Ф. Спецпропаганда

как составная часть партийно-политической работы

в советских Вооруженных Силах

Плеханов А.А. «Господа юнкера, с кем вы были вчера?»

(восстание юнкеров в Петрограде 29 октября 1917 г.

глазами участников и очевидцев)

Истягина-Елисеева E.A. Спортивно-историческое наследие:

проблемы исторических исследований

Макина А.И. Социальная защита детей

в традиционном хакасском обществе

Aнтонова E.Г. Подготовка учительских кадров

в Симбирской губернии в конце XIX - начале XX века

Дегтярева Н.А. ХХ съезд КПСС (к историографии вопроса)................ 364

Kроm H.C. Роль репродуктивных установок

в формировании репродуктивного поведения

(по материалам этносоциологического исследования)

Петрухин А.М. Реакция британской прессы на роспуск

Государственной Думы Российской империи I созыва

ТЕОРИЯ, ФИЛОСОФИЯ И ИСТОРИЯ ПОЛИТИКИ

Власов В.И. Статус Бога в Русской (Российской)

правовой системе (постановка вопроса)

Болтенкова Л.Ф. Библия как источник права (часть пятая)................... 400

Цанава Б.3. Философское наследие Т. Гоббса

и современные либеральные теории

общественного договора

ПОЛИТИЧЕСКИЕ ИНСТИТУТЫ, ПРОЦЕССЫ И ТЕХНОЛОГИИ

Равочкин Н.H. Властные практики

в странах мировой периферии ...

Зубов В.В., Родионова М.Е., Емелин А.А.

Отношение населения к вакцинации от коронавируса:

сравнительный анализ исследований.

Tюков Н.A., Никулин E.P. Российский педагог

в социальных сетях: дискурсивная повестка,

ифровая активность и механизмы коммуникации ......

298 ВОПРОСЫ НАЦИОНАЛЬНЫХ И ФЕДЕРАТИВНЫХ ОТНОШЕНИЙ • ВЫПУСК 2(71) • 2021 • Том 11 
Кочетков $\boldsymbol{E . E . ~ О с о б е н н о с т и ~ ф е д е р а л и з м а ~}$ в арабских странах (на примере Ирака).

Рабат Луджан. Сложности разрешения

сирийского конфликта: внешнее вмешательство

и «либеральный» подход к миростроительству .....

Воскресенский Ф.A. Проблемы судебного федерализма

в политической системе современной России

Денисенко П.В. Big Data в системе отношений

«государство-общество»: потенциал и некоторые

сферы применения (на примере США)

Пилягин К.А. Политические механизмы

(аспекты категориального анализа) 508

Семибоков Д.А. Современная структура

научных представлений о непризнанных республиках

как особых политических институтах

Иванов П.В., Плотников Д.И. Стабилизация

политической системы через государственную политику

национального примирения

ПОЛИТИЧЕСКАЯ КУЛЬТУРА И ИДЕОЛОГИИ

Львов С.В., Максимова А.А., Нечаева С.В. Механизмы

и мотивация участия педагогического сообщества

в политических и гражданских процессах

ТЕОРИЯ И ИСТОРИЯ МЕЖДУНАРОДНЫХ ОТНОШЕНИЙ, ВНЕШНЕЙ И МИРОВОЙ ПОЛИТИКИ

Тушков A.A., Степанова C.C. Противоречия и дихотомии

конфликтного потенциала Восточного Средиземноморья.

Каренин Д.М., Кузьмин В.А. Япония и ЕЭС:

долгий путь к сотрудничеству .

Тушков А.А., Кравченко Ю.С. Россия на международном рынке образовательных услуг. Проблемы и поиски формирования модели интернационализации образования 566

Гехт А.Б., Молчанова Т.В., Цыгоняева А.Ю., Перевозчикова В.А.

Ближневосточный вектор внешней политики США

в период президентства Дональда Трампа

(на примере Ирана и Израиля).

Станкевич И.Г. Река Рейн в восприятии римлян

(І в. до н.э. - начало V в. н.э.). 588

Гехт А.Б., Неровный А.В., Потапенко Т.Г.

На пути к Единой Европе: институциональная архитектура

Европейского объединения угля и стали 594 
Шиматюк О.А. Энергетическое сотрудничество России и Евросоюза в условиях «Зеленой сделки» 603 Антонова Н.Г. Новый альянс «США-Израиль-арабские монархии Персидского залива» в регионе Ближнего Востока: причины сближения и последствия для региональной геополитики

Аржсанов И.А. Арктика в системе современных международных отношений:

лейтмотив соперничества в регионе

Шабловский В.С. Республика Сербская: современные политические реалии и перспективы

Гунду Тересе Мосес, Олувакайоде Олумиде Эммануэль.

Analyzing the Effect of Coronavirus

on Nigeria's Education System/Анализ влияния

коронавируса на систему образования в Нигерии 640

\section{РЕЦЕНЗИИ}

Слизовский Д.Е., Амиантов А. А. Есть ли у правительства ресурсы справиться с протестным движением?

(Рецензия на статью С.И. Морозова и К.М. Макаренко «Технологии регулирования деструктивных форм протестной деятельности в современной России»)

\section{КОНФЕРЕНЦИИ}

Сапрынская Д.В., Сапарбекова Д.С. Международная научно-практическая конференция «Российско-монгольские отношения: от истоков до современности». 661

НАШИ АВТОРЫ 680

ТРЕБОВАНИЯ К ОФОРМЛЕНИЮ РУКОПИСЕЙ 688 
DOI 10.35775/PSI.2021.67.2.036

УДК 32.327

Д.В. САПРЫНСКАЯ

научный сотрудник ИСАА МГУ

имени М.В.Ломоносова,

Россия, г. Москва

Д.С. САПАРБЕКОВА

магистрант Российской академии народного хозяйства и государственной службы при Президенте РФ, Россия, г. Москва

\title{
МЕЖДУНАРОДНАЯ \\ НАУЧНО-ПРАКТИЧЕСКАЯ КОНФЕРЕНЦИЯ «РОССИЙСКО-МОНГОЛЬСКИЕ ОТНОШЕНИЯ: ОТ ИСТОКОВ ДО СОВРЕМЕННОСТИ»
}

\author{
D.V. SAPRYNSKAYA \\ Researcher at the Institute of Asian and \\ African countries, Lomonosov Moscow State \\ University, Moscow, Russia \\ D.S. SAPARBEKOVA \\ Post-graduate student working for the \\ Master's degree at RANEPA under the President \\ of the Russian Federation, Moscow, Russia
}

\section{INTERNATIONAL SCIENTIFIC AND PRACTICAL CONFERENCE "RUSSIAN-MONGOLIAN RELATIONS: FROM THE ORIGINS TO THE PRESENT"}

19 февраля 2021 года в Институте стран Азии и Африки МГУ имени М.В. Ломоносова прошла международная конференция, посвященная 100-летию установления дипломатических отношений между Россией и Монголией. В конференции приняли участие представители дипломатического корпуса двух стран. Представлены были еще ряд стран, среди них представители Турции, Германии, Кыргызстана, Казахстана, Таджикистана, Абхазии, Швеции, Франции, Великобритании, Узбекистана, Египта, Китая, Японии, Украины и др.

Конференция включила в себя пленарное заседание и две сессии. Первая сессия была посвящена вопросам исторического развития отношений между Россией и Монголией, в то время как вторая сессия освещала вопросы современного состояния внешнеполитических отношений двух стран. 
Конференцию открыл Председатель организационного комитета, и.о. директора ИСАА МГУ профессор Игорь Ишеналиевич Абылгазиев, который предоставил слово для приветствия Чрезвычайному и Полномочному Послу Российской Федерации в Монголии господину Искандару Кубаровичу Азизову и Чрезвычайному и Полномочному Послу Монголии в Российской Федерации господина Дуламсурэнгийна Даваа, затем слово взяла директор по развитию международного образования и сотрудничества РАНХиГС Л.Д. Тарадина. В прозвучавших речах было подчёркнуто историческое значение установления отношений между Россией и Монголией. Спикеры отметили, что особую роль в развитии двусторонних связей сыграло то, что именно Россия выступила в качестве первой страны, признавшей Монгольскую Народную Республику

Модераторы: В.А. Родионов (Бурятия, Улан-Удэ), И.В. Зайцев (Россия, Москва), И.В. Кульганек (Россия, Санкт-Петербург).

Пленарное заседание открыл В.А. Михайлов д.и.н., профессор, заслуженный деятель науки Российской Федерации, заведующий кафедрой национальных, федеративных и международных отношений РАНХиГС при Президенте РФ (Россия, Москва) в своем выступлении отметил, что географические особенности евразийского региона, стали объективным фактором, который определяет целостность данной территории и оказали влияние на формирование истории народов, которые заселяют Евразию. Докладчик подчеркнул, что общность исторических судеб евразийских народов, их преемственность и совместимость во многом связана со спецификой континента Евразия и первым евразийским государством была Монгольская империя.

В докладе проф. НИУ ВШЭ, МГИМО (У) МИД РФ С.Г. Лузянин (Россия, Москва) «Россия и Монголия: сто лет отношений. Исторические и современные закономерности» были проанализированы базовые, исторические закономерности российско-монгольских отношений, сформировавшиеся в течение XVII - XX вв., включая особенности советско-монгольского союза - военно-политическую прочность (Халхин-гол 1939 г., разгром японского милитаризма, август - сен. 1945 г.), эффективное оформление международно-правового статуса МНР в 1945-1946 гг., успешную экономическую индустриализацию и реализацию базовых экономических проектов (Эрдэнэт, УБЖД, Дархан и др.). Освещены современные вызовы и особенности, влияющие на характер российско-монгольских отношений - волны глобализации и деглобализации, возвышение и превращение Китая в мировую сверхдержаву, пандемия коронавируса «COVID-19» и др. Профессор выделил три основных направления в развитии двусторонних отношений: 1) развитие двустороннего российско-монгольского стратегического партнерства, оформленного Договором от 3 сентября 2019 г., включающего кооперацию в сферах безопасности, обороны, торговли, инвестиций, инфраструктурных проектов, гуманитарного сотрудничества и др.; 2) взаимодействие России 
и Монголии с Китаем, развитие экономического коридора «Монголия Россия - Китай», сопряжение с китайской инициативой «Один Пояс, Один Путь», подготовку к реализации углеводородного проекта «Сила Сибири 2» через Монголию; 3) российско-монгольскую кооперацию в рамках региональных организаций: в ШОС, в которой Монголия - наблюдатель, и с Евразийским экономическим союзом (ЕАЭС) в плане подготовки создания Зоны свободной торговли между ЕАЭС и Монголией. В завершении своего доклада С.Г. Лузянин подчеркнул, что «главное сегодня, это - сохранение наших традиционных ценностей и достижений, независимо от эпох и идеологий. За сто лет все ненужное и негативное отсеялось, ушло в прошлое, а все положительное и взаимополезное осталось и окрепло».

С докладом на тему: «Россия и Монголия: к истории установления двусторонних отношений» выступил в.н.с. Института Востоковедения РАН (Россия, Москва) А.Ш. Кадырбаев, который подробно остановился на процессе установления отношений между двумя странами, истоки которых уходят в глубь веков, в события XIII века, когда была создана мировая Монгольская империя, в состав которой вошли земли, где ныне Россия, и русские с монголами были подданными одного государства, что наложило неизгладимый отпечаток на историю России. Российско-монгольские отношения получили новый импульс для развития в XVII в., когда русские землепроходцы присоединили к России Сибирь и дошли до Тихого океана, на пути к которому устанавливали связи с государствами на землях нынешней Монголии - Алтын-ханов, Джунгарским ханством, причем, монгольский язык стал для русских в это время языком общения не только с монгольским миром, но и с Китаем. Но взлет российско-монгольских отношений приходится на XX в., когда, опираясь на поддержку России, в 1921-1961 гг. была возрождена и упрочена монгольская государственность, новый отсчет истории которой начался с образования Монгольской Народной Республики, выстрадан в союзе с Россией в борьбе за независимость против Японии и Китая, когда благодаря решениям лидера СССР И.В. Сталина, Монголия после второй мировой войны стала членом $\mathrm{OOH}$ и субъектом международного права.

Следующим выступающим была И.В. Кульганек, д.филол.н., зав.сектором Центральной Азии отдела Центральной и Южной Азии ИВР РАН (Россия, Санкт-Петербург). Доклад на тему «1930 год: подарок ученого комитета Монгольской Народной Республики Академии наук СССР» был посвящен Альбому фотографий «Северная Монголия. Ландшафты. Дар Ученого комитета Монгольской Народной Республики Академии Наук СССР. 1930 г.», который хранится в Архиве востоковедов Института восточных рукописей РАН под шифром С 11. Альбом является актом выражения дружбы и сотрудничества монгольской и российской научных организаций. Он был преподнесен в преддверии 10-летней юбилейной даты образования Уче- 
ного Комитета Монголии и подписания договора о сотрудничестве между Монголией и Россией. Альбом представляет собой рукописное подарочное издание, выполненное в виде книги из сшитых картонных листов, на которые наклеены 55 черно-белых фотографий. На фотографиях изображены природные и этнографические объекты, культовые места, памятники архитектуры и скульптуры северной части Монголии. Докладчик прокомментировал фотографии, представленные в Альбоме. Проведя исследование времени съемки, выбранных объектов, особенностей оформления книги, он высказал соображение об авторстве Альбома.

Представитель Монголии из г. Улан-Батор проф. Монгольского университета поствысшего образования, д.э.н. Х. Батцэнгэл представил доклад на тему: «Научно-образовательное пространство в перспективе двусторонних отношений». Ученый отметил, что системно-пространственный анализ позволяет представить перспективу дальнейшего развития сотрудничества в области науки и образования двух стран в направлении формирования научно-образовательного пространства. При этом надо признать, что в такой модели анализ развития двусторонних отношений за 100-летний период давал вполне определенные, обоснованные научные результаты, что позволило в какой-то мере объективно оценить состояние этих отношений и определить перспективу их развития. Однако в таком анализе становится невозможным осмысление этих отношений в многомерном пространстве, как живой, динамической системе, где своего рода энергетическая мощь двух народов проявляется во всем своем разнообразии. Тем более исторический анализ любой живой системы, каковой является в частности и система двусторонних отношений между нашими странами и народами, наше сотрудничество в области науки и образования, невозможен без глубокого системно-пространственного осмысления всего происходящего в живой системе, понимания его первичной единицы, из которой вырастает сама система, даже ее генетического кода, хранящегося в исторической памяти, цивилизационной основе существования народов.

Далее слово взял К. Дэмбэрэл - доктор (Ph.D.), ст.н.с. Института международных отношений Академии наук Монголии, координатор Центра изучении Центральной Азии при ИМО, (Монголия, Улан-Батор). Тема выступления звучала следующим образом: «Монголия перед дилеммой ШОС и Шелковый путь. Ученый отметил, что у Монголии имеется статус наблюдателя ШОС. Это значит, что Монголия является неполноправным членом. В то время как главным локомотивом ШОС выступают КНР и РФ, у которых, впрочем, есть ряд разногласий в перспективах развития данной организации. Монголия же имеет партнерские отношения с обеими странами. Монголия полностью поддерживает инициативу КНР «Один пояс, один путь» и выступает с предложением своего проекта «Степной путь» как составной части проекта «Нового шелкового пути». Если данная инициатива 
не найдет широкой международной поддержки, то перед Монголией встанет вопрос выбора - ШОС или Шелковый путь.

Б. Батхишиг, д.э.н., проф. Института философии АН Монголии (Монголия, Улан-Батор) выступил с докладом на тему: «Основные этапы развития Монголии и ее отношений с Россией в прошлом и нынешнем веках. Профессор подчеркнул, что Монголия, которая в XIII-XIV веках держала под своим руководством большую часть огромного Евразийского континента, в конце XVII века попала под сюзеринитет Циньской династии Китая и находилась в этом положении вплоть до начала XX века. К счастью, этот $\mathrm{XX}$ век оказался очень знаменатальным для приобретения независимости и возрождения Монголии. Именно с национально-освободительной революции Монголии 1911 года началась новая эра развития Монголии, которая делится на следующие этапы:

1) этап борьбы за независимость /1911-1924/;

2) этап борьбы за полную независимость или этап некапиталистического пути развития Монголии /1924-1961/;

3) социалистический этап развития Монголии /1961-1990/;

4) демократический этап развития Монголии /1990 - до нынешнего времени/.

Профессор Б. Батхишиг подчеркнул: «Каждый этап развития Монголии тесно связан с отношениями и сотрудничеством с Советским Союзом и Россией».

В своем докладе на тему: «Российско-монгольские отношения: анализ двусторонних договоров» Ж. Баттогтох Ph.D. (МУИС ОУХНУС), д.философ.н., профессор, декан факультета международных отношений и государственного управления (Монголия, Улан-Батор) обратила внимание на то, что взаимоотношения между Россией и Монголией, заложенные еще 5 ноября 1921 года носят характер стратегического партнерства. Подчеркнула, что после распада СССР, в новых геополитических условиях между странами был заключен Договор о дружественных отношениях и сотрудничестве и это произошло в 1993 году. Отношения между странами имеют фундаментальную опору - это и декларации, заключенные в Улан-Баторе в 2000 году, и в Москве 2006 г., декларация о развитии стратегического партнерства между Российской Федерацией и Монголией от 25 августа 2009 г. Между странами на государственном и межправительственном уровне заключено более 150 договоров, что является основой для дальнейшего сотрудничества Монголии и России.

Л.В. Курас, д.и.н., профессор, гл.н.с. отдела истории и культуры Центральной Азии Института монголоведения, буддологии и тибетологии СО РАН (Россия, Улан-Удэ) выступил с докладом на тему: «Отто Иванович Макстенек: у истоков двусторонних отношений между Россией и Монголией». Ученый отметил, что между тем у истоков двухсторонних дипломатических отношений Советской России и Монголии стоял другой советский дипломат - член партии большевиков с 1904 г., политкаторжанин Отто Ива- 
нович Макстенек, имя которого оказалось незаслуженно забытым. В июне 1920 г. в пограничном городе Троицкосавске начало работать представительство НКИД Советской России в Монголии, во главе которого встал Уполномоченный НКИД РСФСР в Монголии О.И. Макстенек. Дело в том, что он не был пропущен китайскими оккупационными властями в Ургу и был вынужден остановиться на границе. Обосновавшись в Троицкосавске, дипломат приступил к налаживанию контактов с монгольскими революционерами и организации их связи с представителями Советской власти и Коминтерна в Сибири.

В.А. Родионов, д.полит.н., директор Института востоковедения Бурятского государственного университета им. Банзарова (Россия, Улан-Удэ) в своем докладе на тему: «Индия как «третий сосед Монголии» подчеркнул, что в основу внешнеполитической стратегии Монголии положен приоритет развития отношений по трем главным направлениям - сотрудничество с Россией, Китаем и «третьим соседом», включающим в себя США, государства ЕС, Японию, Республику Корея. Отдельное место в этом ряду занимает Республика Индия. На фоне незначительной роли Индии во внешнеэкономической деятельности Монголии привлекает внимание особый характер отношений между странами в культурно-религиозной сфере. Высокопоставленные политики обеих стран неоднократно указывали на «духовную близость», основанную на буддийской религии. Кроме того, в последние годы индийская сторона сделала ряд шагов по наращиванию своего влияния в Монголии. Речь идет, прежде всего, о выделении крупного кредита на строительство НПЗ, расширении сотрудничества в области IT-технологий и кибербезопасности, предоставлении партии вакцины от COVID-19. В свете усиления индийско-китайских противоречий активизация политики НьюДели на монгольском направлении может быть интерпретирована как часть геополитической стратегии по сдерживанию КНР.

Далее с докладом на тему «Российско-монгольские отношения в эпоху глобализации» выступил С.А. Семедов, д.филос.н., профессор РАНХиГС при Президенте РФ (Россия, Москва), который обратил внимание участников встречи на то, что за сто лет дипломатических отношений между двумя странами не было конфликтных ситуаций, нет принципиальных разногласий по проблемам мировой политики и это является важным фактором, который прочно укоренился в памяти наших народов. Спикер выразил уверенность в динамичном развитии торговых и экономических отношений. Он отметил большой накопленный опыт взаимоотношений в различных сферах и подчеркнул, что «Монголия и Россия - это две разные культуры, две разные цивилизации, но с глубоким пониманием друг друга. Надо органично развивать единое образовательное, спортивное и культурное пространство, которое будет поддерживать и углублять отношения между нашими народами». 
А.И. Сухарев, д.полит.н., профессор РАНХиГС при Президенте РФ (Россия, Москва) в своем докладе на тему «Российско-монгольское гуманитарное сотрудничество» затронул темы огромной поддержки нашей страны монгольским народом в годы Великой Отечественной войны, русского языка, широко распространенного в Монголии. В то же время, как отметил эксперт, интерес к русскому языку у современной молодежи снижается, в старших классах его изучение стало факультативом. «Должна быть создана специальная совместная программа по подготовке и переподготовке преподавателей русского языка для монгольских школ, - сказал Сухарев. - Надо поддерживать и развивать знание русского языка, который объединяет наши народы».

С докладом на тему «История русской диаспоры в Монголии и ее вклад в развитие двусторонних отношений» выступила Т.В. Шорваева, член Всемирного координационного совета российских соотечественников за рубежом, председатель координационного совета организаций российских соотечественников в Монголии (Монголия, Улан-Батор), которая рассказала о наличии отдельных групп русских в Монголии, переселившихся в 18-19 веках, что было отмечено русскими путешественниками Козловым, Пржевальским, Потаниным, Обручевым, Владимирцовым. Селились они главным образом в долинах рек: Селенги, Онона, Орхона и Тэс. Это были крестьяне-староверы (семейские), притеснявшиеся царским правительством и РПЦ, беглые крестьяне и др. Докладчик так же обратила внимание на участие русских в индустриализации Монголии. Большую роль в развитии государства и ее экономики вместе с монгольскими гражданами и специалистами из СССР играли и постоянно проживающие в Монголии советские граждане, они трудились, практически, во всех сферах. Их труд высоко оценен Монголией, многие из них были награждены государственными наградами.

В завершающей части пленарного заседания выступил студент из Монголии Цогоо Дорж, обучающийся на факультете маркетинга и международного сотрудничества РАНХиГС, по направлению «Международное сотрудничество» выступил с сообщением на тему: «Образ России и русских в общественном сознании современной монгольской молодежи».

Модераторами первой сессии выступили Н.Т. Нурулла-Ходжаева, д.филос.н. (Россия, Москва) и Г.Д. Джунушалиева, д.и.н., профессор (Кыргызстан, Бишкек).

Выступающие первой сессии, с подачи модераторов, начали свое обсуждение со ссылки на выступление Чрезвычайного и Полномочного Посла Российской Федерации в Монголии господина Азизова Искандара Кубаровича, в частности, его ремарку по поводу «многостранового» подхода в представлении Монголии, ее вклада в историю, культуру и современность Евразии, что дало ориентацию на более расширенное обсуждение обозначенной темы конференции.

А.Н. Команджаев, д.и.н., профессор, заведующий кафедрой истории России, документоведения и архивоведения Калмыцкого государственного 
университета (Россия, Калмыкия, Элиста), первый выступивший на сессии, в своем докладе на тему: «Изучение монгольской цивилизации: российские калмыки в конце XIX века» говорил о роли монгольской цивилизации в формировании калмыкского этноса. В результате цивилизационно-культурного столкновения между Джунгарским ханством и Цинским Китаем, выжившая часть населения вынуждена была мигрировать на запад. В материальной культуре калмыков сохранились значительные пласты социальной и традиционной специфики монгольской кочевой цивилизации. Но, со временем, с распространением российской правовой системы на территориях Калмыкии очень многие характерные кочевнические социальные нормы теряют свое былое значение.

Далее выступила представитель Кембриджского Университета Праджакти Калра, к.и.н., Центр исследований по развитию (Великобритания, Кембридж). Ее доклад на тему: «Влияние Золотой Орды на отношения России, Центральной Азии и Монголии» вызвал оживленную дискуссию среди коллег. Докладчик подчеркнула, что помимо содействия торговле, влияние монголов также улучшило сообщение вдоль Великого Шелкового пути (ВШП), установив почтовую ретрансляционную систему. Выступающая также особо отметила, что устойчивые экономические связи сумели создать коммуникационную площадку для торгового и социокультурного обмена между этносами. Не менее значимым товаром наряду с шелком на маршрутах ВШП был мех, который ценился и был востребован на рынках Европы. Как отметил спикер, «Исследования развития экономических и международных отношений между Золотой Ордой, Россией, Центральной Азией и Монголией можно существенно дополнить изучением других аспектов регионального взаимодействия».

Доклад М.И. Алиевой-Чынар, к.филол.н., доцента Улудгского Университета (Турция, Бурса) «Суфизм - синтез Православия и тюрко-монгольского Тенгризма» оказался весьма спорным, и одновременно открыл другую плоскость интерпретации суфизма на Евразийских просторах. Исследователь подчеркнула, что монголы культурно расширили Шелковый путь, позволив людям разных религий сосуществовать. Слияние народов и культур завоеванных территорий принесло свободу вероисповедания по всей империи. Через обширные степи Азии путешественник мог встретить мусульман и христиан, живущих и работающих вместе с монголами, которые продолжали исповедовать свою традиционную религию. С точки зрения докладчика суфизм практически совместил в себе догматы православного христианства с духовными практиками тюрко-монгольского тенгризма. Докладчик резюмировал, что именно благодаря подобному синтезу, суфизм сумел укрепить позиции ислама в Центрально-Азиатском регионе.

М. Фазылхашеми, Ph.D., проф. Исламской теологии и философии Университета Упсалы, член Шведской Академии наук (Швеция, Стокгольм) 
и М. Наматов, Ph.D., проф., исследователь университета Новый Лиссабон (Португалия, Лиссабон) представили выступление на тему: «Концепция власти аль-Газали и монгольская династия Джучидов». В докладе было отмечено, что Джучиди, являющиеся в XIII-XVII вв. правителями различных государств в Восточной Европе, Центральной Азии, Западной Сибири и Дешт-и-Кипчаке оказали огромную роль на процессы, происходившие в большом пространстве Евразии. Докладчики подробно остановились на концепции интеллектуального и толерантного российского Ислама синтеза монгольского шаманизма и персидского Зороастризма.

М.А. Наматов, ассоциированный исследователь университета Новый Лиссабон, факультета истории и культуры народов Азии, профессор, Ph.D. (Германия) отчасти продолжил идею предыдущего спикера, поскольку его доклад был посвящен другому аспекту суфизма: «Влияние монголо-тюркского Тенгризм на концепцию суфизма в тюркском (российском) исламе. Концепция религиозной толерантности и противостояния салафизму». В докладе было сказано, что стабильность, принесенная монгольским правлением, открыла возможности циркуляции идей по религиям между народами из Центральной Азии в Восточную Азию. Выступающий отметил, что между суфизмом и салафизмом существуют достаточно серьезные расхождения, которые обусловлены излишним радикализмом и нетерпимостью к другим мусульманам и немусульманам. Суфизм с его ориентацией на духовное познание через собственные чувства и ощущения, практику достижения экстаза с помощью музыки и танцев, народные верования, посещения гробниц с подношениями, клятвы и обращения к святым вызывают резкую критику салафитов.

Далее на сессии выступил Б.В. Меняев, специалист наук ФГБОУ КалмГУ им. Б.Б. Городовикова (Россия, Калмыкия, Элиста), который очень последовательно раскрыл тему, касающуюся «Экспедиций калмыцких ученых в Монголию, Китай и Киргизию». Вопросы по поводу масштабов такого рода экспедиций, были встречены активной дискуссией среди слушателей. Было признано, что сама тема «экспедиций», это возможная платформа по обоснованию и дальнейшим исследованиям народов, живущих на этих землях. Докладчик особо отметил роль калмыцких исследователей в изучении артефактов материальной культуры этнических групп калмыков, которые проживают на территории Монголии, Китая и Киргизии. Этнографические и археологические памятники позволили провести параллели между ними, собрать аналитический материал, который стал основой для дальнейших научных публикаций. Данный доклад был подготовлен совместно с Б.X. Борлыковой, к.филол.н., ФГБОУ КалмГУ им. Б.Б. Городовикова (Россия, Калмыкия, Элиста).

Следующий представитель Калмыкии, Б.Л. Митруев, научный сотрудник Калмыцкого научного центра Российской Академии Наук (Россия, 
Калмыкия, Элиста) представил доклад на тему: «Рукописи эпоса Гэсэр из фонда Калмыцкого научного центра». Докладчик кратко, но весьма поучительно продемонстрировал имеющиеся рукописи Фонда и последующие перспективы их изучения. Калмыцкое сказание Гэсэр представляет собой цельный сюжет, в котором обнаруживаются параллели с главами известных сводов тибетских и монгольских версий эпического памятника. Наблюдаются совпадения отдельных сцен, мотивов; некоторые мотивы и сюжеты даются в кратком изложении, а некоторые упоминаются лишь фрагментарно. Сюжет, имея генетические схождения с тибетскими и монгольскими эпическими версиями, на почве калмыцкой фольклорной традиции претерпел трансформации и модификации на содержательном и сюжетно-мотивном уровнях, с признаками сказочного переосмысления.

Большой интерес вызвал доклад Н.Г. Очировой, к.полит.н., ФГБУН «Федеральный исследовательский центр. Южный научный центр РАН» (Россия, Ростов-на-Дону), «Монголоведные исследования в Калмыкии: история и современность», в котором исследователь показала, значимость и актуальность современного монголоведения в Калмыкии.

В своем докладе на тему «Студенты Ленинградского Восточного Института (1920-1938): между классическим и прикладным монголоведением», н.с. Санкт-Петербургского Института восточных рукописей РАН, к.филол.н. Д.А. Носов (Россия, Санкт-Петербург), поднял вопросы по истокам и преемственности отечественного монголоведения, подчеркнув актуальность такого рода работы среди современных исследователей.

Затем слово для выступления взял Р.Р. Назаров, доцент кафедры Иностранных языков и гуманитарных дисциплин Ташкентского филиала РЭУ имени Г.В. Плеханова (Узбекистан, Ташкент). Его доклад «Советско-монгольское военно-политическое сотрудничество в 1920-1940-е гг.» стало началом серии докладов, посвященных вкладу Монголии, и в целом сотрудничества Монголии и Советского Союза в период 20-х - 40-х гг.

Следующим докладчиком был Э.У. Шорваев, к.и.н., Генеральный директор ООО «Открытый мир» (Монголия, Улан-Батор). Его доклад: «Г.К. Жуков - роль личности в истории советско-монгольских отношений» был встречен слушателями с большим интересом. Докладчик признал, что полководческое искусство Г.В. Жукова признано в мире и это было доказано также в процессе боев на Халхин-голе. Исследователь подчеркнул какую высокую оценку дает монгольский народ Г.К. Жукову в разгроме японских агрессоров и в дальнейшем укреплении вооруженных сил Монголии.

Доцент кафедры ЮНЕСКО ИСАА МГУ имени М.В. Ломоносова В.Л. Пархимович (Россия, Москва) в своем докладе «Поездка председателя Президиума Верховного Совета СССР К.Е. Ворошилова в МНР в 1957 году» говорил о том, как 26 мая 1957 года в столицу МНР Улан-Батор прибыл с визитом дружбы К.Е. Ворошилов. Отдельно докладчик остановился на результатах этого 
визита. Спикер отметил, что это был первый визит в МНР высшего должностного лица СССР, ранее ни один глава Советского Правительства, Президиума Верховного Совета СССР или первый секретарь ЦК КПСС не посещали эту страну. Визит К.Е. Ворошилова содействовал росту международного престижа МНР, интеграции страны в систему мировой политики, интенсификации дипломатических контактов Монголии с социалистическими и развивающимися странами, что способствовало вступлению МНР в ООН в 1961 г.

А.А. Ганич, к.и.н., н.с. лаборатории экологии культуры Востока ИСАА МГУ имени М.В. Ломоносова (Россия, Москва) выступила с докладом на тему: «Монголы в армянских источниках XIII - XIV вв.». Исследователь выделила наиболее значимые сочинения армянских авторов и среди них такие труды: Григора Акнерци (Магакии) [«История монголов инока Магакии, XIII в.»], Вардана Аревелци [«Всемирная история Вардана Великого»], Мхитара Айриванеци [«Хронологическая история, составленная отцом Мхитаром, вардапетом Айриванским»], Степаноса Орбеляна [«История области Сисакан»], Киракоса Гандзакеци [«История Армении»], Гетума (Хетума) Патмича [«Цветник историй стран Востока»], Смбата Спарапета, Степаноса епископа, Безыменного Себастаци, Иоанна Ерзынкаци, Нерсеса Палиенца и др. Все вышеперечисленные авторы, являясь современниками описываемых событий, довольно подробно повествуют о нашествиях монголов и их последствиях для местных народов, о взаимоотношениях с местными владетелями, быте, нравах и религиозных представлениях монголов, об особенностях военного дела, системе управления и налогообложения на завоеванных территориях.

Доклад на тему: «Институт зятьев в Монгольской империи» был представлен К.Ш. Хафизовой, академиком Казахской Национальной академии естественных наук (КазНАЕН), главным научным сотрудником Центра сближения культур второй категории под эгидой ЮНЕСКО Министерства культуры и спорта Республики Казахстан (Казхстан, Алматы). Выступление академика вызвало весьма оживленный интерес у участников конференции, так как затрагивало интересные моменты, связанные с обычаями и традициями монгол.

К.И. Кобландин, д.и.н., профессор ЕНУ им. Л.Н. Гумилева и Байжума Г., докторант Ph.D. (Казахстан, Нур-Султан) представили совместный доклад на тему: «Этнодемографическое развитие казахов Монголии во второй половине XIX и в первой четверти XXI века». Ученые исследовали динамику изменения демографических показателей казахского населения Монголии, выделив аймаки, где проживает наибольшее количество этнических казахов.

Д.и.н., профессор Карагандинского университета имени Е.А. Букетова 3.Г. Сактаганова (Казахстан, Караганда) заявила тему доклада: «Казахи Монголии: к проблеме возвращения на историческую родину в 1990-2000-е годы». В докладе были подняты проблемы возвращения казахов на истори- 
ческую родину на рубеже XX-XXI веков. Исследованы общие закономерности и особенности их расселения и адаптации в Центральном Казахстане. На материалах статистических данных текущего архива миграционных служб Республики Казахстан изучены основные этапы миграции оралманов из Монголии.

Вышеназванную тему поддержала в своей речи Б.А. Досова, к.и.н., доцент кафедры всемирной истории и международных отношений Карагандинского университета имени Е.А. Букетова (Казахстан, Караганда). Тема ее доклада: «Кандасы в истории казахстанско-монгольских отношений». В нем она остановилась на основных аспектах истории возвращения из Монголии этнических казахов на историческую родину, их адаптации в казахстанском обществе. Отметила роль кандасов и граждан Монголии казахской национальности в укреплении казахстанско-монгольских отношении.

Д.Я. Рахаев, к.и.Н., с.н.с. Института Российской истории РАН (Россия, Москва) выступил с докладом на тему: «Черкесы в составе Монгольской империи». В своем выступлении исследователь выделил те источники, в которых упоминают черкесов, занимавших важные посты в войске и администрации монголов. Подчеркнул, что необходимо признать, что экономическое бремя, которое ханы наложили на черкесов, частично компенсировалось тем, что: во-первых, адыгская знать, участвовавшая в имперских военных кампаниях, получала свою долю добычи; и, во-вторых, адыги в числе прочих участников приобретали выгоду от расширения международной торговли в условиях мира между народами, входившими в Монгольскую империю. Военная добыча и торговля, несомненно, смягчали ущерб от оттока экономических и людских ресурсов в годы вхождения Черкесии в Джучиев улус.

Следующим докладчиком был Д.М. Тимохин, к.и.н., с.н.с. Института Востоковедения РАН (Россия, Москва). Тема его доклада: «Монголы в арабо-персидских источниках». Исследователь подчеркнул, что корпус источников о монгольском нашествии на Центральную Азию был неоднороден: в нем сосуществуют различные по своей языковой и культурной принадлежности произведения, отличающиеся по структуре, замыслу, характеру описаний и составу упоминаемых событий. И это, несомненно, актуально для работы по данному направлению.

Далее с докладом на тему «Монгольские образы в персидской миниатюре» выступила Н.Т. Нурулла-Ходжаева, д.филос.н., доцент кафедры Центральной Азии и Кавказа ИСАА МГУ имени М.В. Ломоносова. Она подчеркнула, что никакое художественное движение не возникает, не имея контактов с другими устоявшимися направлениями в искусстве. Так обстоит дело с «персидской миниатюрой» и влиянием китайско-монгольских образов в ней. Маверанахр на протяжении веков придавал огромное значение искусству и культуре из вне, и это вело к возникновению очень любопыт- 
ных вариантов синтезов самых различных художественных стилей. Докладчик проиллюстрировала доклад миниатюрами гератской и бухарской школ миниатюристов.

И.А. Зайцев, аспирант ИСАА МГУ имени М.В. Ломоносова в своем докладе на тему: «Образ Хубилай-хана как государя Чакравартина в отражении одной бирманской надписи» анализирует текст надписи на каменной стеле, расположенной в хранилище Паганского археологического музея в республике Союз Мьянма. В источнике упоминается информация о совершении паломничества буддийским монахом Дитапамау ко двору императора династии Юань Хубилай-хана в конце XIII столетия (1287 г.) после очередного похода монгольских войск на Бирму.

Также представили свои доклады еще ряд участников конференции, среди них: Д.А. Кемешев, д.пед.н., профессор, член-корреспондент МАН ПО Южно-Казахстанского государственного педагогического Университета (Казахстан, Шымкент) с докладом на тему: «Философия Великой степи»; А.М. Тюрин, к.геол.-минер.н., доцент Оренбургского государственного университета (Россия, Оренбург) с докладом на тему: «Имеются ли генетические следы контактов русских с монголами?»; Г.И. Матрюхин, д.и.н., профессор Московского государственного университета печати (Россия, Москва) с докладом на тему: «Книжная культура Монголии. История и современность»; Н.И. Сенченко, д.т.н., профессор, Генеральный директор Украинской книжной палаты (Украина, Киев) с докладом на тему: «Монгольская книга в Украине: культурно-исторический аспект»; Б.С. Есенькин, д.э.н., профессор, президент Торгового Дома «Библио-Глобус» (Россия, Москва) с докладом на тему: «Книга, как символ и инструмент сплочения наших народов»; Е.С. Карауш, редактор ГК «Просвещение» (Россия, Москва) с докладом на тему: «Использование современных цифровых образовательных ресурсов для изучения русского языка как иностранного»; С.С. Вдовин, аспирант ИСАА МГУ имени М.В. Ломоносова (Россия, Москва) с докладом на тему: «К вопросу о русско-монгольских торговых отношениях в конц 19 - начале 20 вв.».

В целом, в итоговых ремарках по завершению первой сессии было сказано о том, что в историческом плане взаимодействие нескольких цивилизаций - монгольской, тюркской, славянской, персидской, - в период монгольского господства на континенте оказалось самым плодотворным и захватывающим в истории развития государств, этносов и религий. И на современном этапе Монголия играет важную международную роль в евразийских экономических интеграционных процессах. И это подводит нас к актуальности продолжения работ, которые расширят потенциал монголоведения по всему миру. Чему и была посвящена вторая сессии нашей конференции.

Модераторами второй сессии выступили д.филос.н., профессор С.А. Сeмедов (Россия, Москва), к.и.н., доцент О.В. Лушников (Россия, Пермь), профессор Н.А. Наматов (Франция, Париж). 
С докладом на тему «Монголия в рамках ШОС: геополитическая стратегия между Россией и КНР» выступила Г.Д. Джунушалиева, д.и.н., профессор Киргизско-Российского Славянского университета (Кыргызстан, Бишкек). В своем докладе профессор отметила, что глобальные интеграционные процессы 21 века требуют региональной международной консолидации сил в контексте однополюсного мира. Монголия, как и ряд других стран Центральной Азии, открывается для регионального сотрудничества и встраивается в евразийскую систему международных организаций. Одной из таких структур является ШОС, возникшая первоначально как центр по противостоянию международному терроризму, экстремизму и сепаратизму, за прошедшие годы разработала программу экономического регионального сотрудничества. Экономическая компонента деятельности ШОС побуждает к принятию взвешенного решения об изменении статуса наблюдателя на полноправного члена организации.

Ж.С. Сыздыкова, д.и.н., профессор, заведующий кафедрой стран Центральной Азии и Кавказа Института стран Азии и Африки МГУ имени М.В. Ломоносова (Россия, Москва) заявила тему доклада: «Основные аспекты внешней политики Монголии на современном этапе». В своем выступлении она отметила, что в 1990-е гг. в Монголии была принята новая Конституция, страна получила вместо старого названия МНР, новое - Монголия. Появилась и новая Концепция внешней политики. Традиционные партнеры Монголии это Россия и Китай. Одним из важнейших направлений внешней политики стала концепция «третий сосед». Поначалу «третьим соседом» именовали США, а со временем к ним начали относить развитые государства, которые имеют, как правило, геополитические и экономические интересы в регионе, например, Япония. Следующее направление внешней политики Монголии заключается в развитии дружественных двусторонних связей со странами Азии, и, конечно же продолжение активного сотрудничества с $\mathrm{OOH}$ и развитие двусторонних отношении с развивающимися странами.

Следующими слово взяли ученые: Биссио Беатрис, Ph.D. проф. Федерального университета (Бразилия, Рио-де-Жанейро) и Н.A. Наматов, Ph.D. проф., член Парижского Азиатского Общества (Франция, Париж) с докладом на тему: «Геополитика Китая в отношении Монголии, ЦА и роль РФ». В докладе исследователи отметили, что динамика неравномерного развития постоянно подрывает основы установившегося мирового порядка. Факт заключается в том, что какими бы ни были причины и их объяснения - 21-й век представляет собой все более многополярный международный сценарий. И в этом выделяются два важных участника - Россия и Китай, которых по этой самой причине, силы американского истеблишмента рассматривают как величайшие вызовы своим гегемонистским претензиям. Укрепление позиции Монголии также будет на радаре Вашингтона, в частности, в плане ее сближения с Китаем, но пока она не вызывает такого же беспокойства. 
Ламбаль Ален, Ph.D. проф. Академии заморских территорий (Франция, Париж) и H.A. Наматов, Ph.D. проф., член Парижского Азиатского Общества (Франция, Париж) в своем выступлении на тему: «“Наследники Бабура и Великих Моголов” и геополитика Пакистана в Центральной Азии, Монголии» отметили, что бабуризм - это официальная внешнеполитическая доктрина Пакистана, направленная на расширение сферы влияния на соседние территории с помощью «мягкой силы» из-за экономики, гуманитарного воздействия и наднационального духа. Внутриполитический национализм Пакистана и сегодня не утратил свое былое значение, вместе с новыми наднациональными связями, основанными на имперском мышлении современного типа, умеренном исламе, пакистанском евразийстве, панисламизме и идее бабуризма. Центральная Азия рассматривается в контексте страны ЦА, Алтая, СУАР, часть Тибета, Монголии и Афганистана.

М.3. Шахиди, д.и.н., профессор Таджикского государственного университета (Таджикистан, Душанбе) выступила с докладом на тему: «Роль Центральной Азии в формировании новых международных отношений между Россией и Монголией». Профессор подчеркнула, что развернуть обсуждение празднования 100-летия дипломатических отношений России и Монголии невозможно без учета роли и вклада Центральной Азии в РоссийскоМонгольские дипломатические отношения. В докладе было сказано, что принято считать, что концепция дипломатии оформилась в эпоху модерна в Англии в XVII в. Однако еще в XV в. ряд государств отмечали роль дипломатической миссии посла Короля Испании Энрике III во Двор Амира Тимура в 1403-1406 годах. Именно формирование дипломатических связей в эпоху Тимура наряду с новыми социологическими исследованиями Ибн Халдуна, решительно повлияло на изменение траектории поэтической мысли и заложило межкультурное направление новой поэтики модерна Центральной Азии, инициированные двумя выдающимися поэтами той эпохи, Джами и Навои. Однако осмысление этого периода, стало приоритетным направлением академических школ Восточной Евразии второй половины $\mathrm{XX}$ в. Одной из важных платформ такого изучения стала Центральная Азия и, особенно, Таджикистан.

Е. Гаврилина-Фудзияма, Генеральный менеджер международной компании "Pacific Partners Tokyo Co., Ltd. Member of Protocol\& Diplomacy International - Protocol Officers Association (founded 2002 Washington D.C.) (Япония, Токио) в своем выступлении на тему: «Некоторые аспекты сотрудничества Монголии и Японии на современном этапе» подчеркнула, что дипломатические отношения между Монголией и Японией были установлены 24 февраля 1972 года. С этого времени отношения в разных сферах деятельности вплоть до 1991 года развивались последовательно. Монголия сыграла важную роль в урегулировании конфликта на Корейском полуострове. Япония помогла Монголии преодолеть экономический кризис 1990-х годов, 
благодаря безвозмездной помощи и льготным кредитам. В августе 1991 г. премьер-министр Японии Т. Кайфу прибыл в Монголию с визитом и стал первым главой, который не принадлежал к «советскому лагерю» государств, посетившим Монголию. В настоящее время динамичное развитие политических и экономических отношений вывело страны на новый уровень взаимоотношений, имеющий взаимовыгодный характер. Происходит развитие по многим направлениям, образование, культура, экономика, политика, что говорит о постоянном развитии диалога и сотрудничества двух стран.

О.В. Лушников, к.и.н., доцент ГГПУ, директор Центра Евразийских исследований им. Г.В. Вернадского (Россия, Пермь) подготовил доклад на тему: «Россия и Монголия - стратегическое партнерство на Евразийском пространстве». Докладчик обратил внимание на влияние монгольской миросистемы Pax Mongolica XIII-XV вв. на формирование Московского государства (госуправление, организация армии, развитие технологий, культуру и быт). Отметил фундаментальную помощь России (СССР) в XX в. в возвращении фактической независимости Монголии от Китая в 1911-1924 гг., оборону Монголии от японско-маньчжурской агрессии 1939 г., в международном признании МНP ООН (1945-1961 гг.), а также комплексную поддержку в сферах безопасности, экономики, здравоохранения, образования и культуры МНР (1945-1990 гг.), а также сказал о перспективах стратегического взаимодействия России и Монголии в рамках ШОС, ЕАЭС и Большого Евразийского партнерства, как гарантий безопасности и развития во всех сферах в XXI в.

С.С. Джеенбекова, к.и.н., доцент, представляющая Киргизско-Российский Славянский Университет (Кыргызстан, Бишкек) выступила с докладом на тему: «Геополитика Монголии со странами Центральной Азии, Россией, Китаем и АТР». Докладчик выделила актуальные вопросы взаимоотношений Монголии со странами ЦА, Россией, Китаем и АТР, исходя из концепции стратегического партнёрства и традиционного исторического добрососедства. Особо подчёркнут вопрос о роли РФ как влиятельного игрока в ЦА, развивающей интеграционный проект - ЕАЭС.

О.А. Машкина, к.пед.н., доцент кафедры китайской филологии ИСАА МГУ имени М.В. Ломоносова (Россия, Москва) представила совместный доклад с В.В. Кузнецовой, к.и.н, доцентом кафедры госуправления МГУ имени М.В. Ломоносова (Россия, Москва). В своем выступлении докладчики отметили, что политика открытости, проводимая руководством КНР с конца 1980-х гг. включает два аспекта/направления (в страну и из страны): а) привлечение иностранных студентов, преподавателей, передовых технологий и учебных материалов в китайские вузы с тем, чтобы поднять качество обучения и международный рейтинг вузов; б) поощрение китайской молодежи к обучению в зарубежных вузах. Нельзя сказать, что проект «Один пояс, один путь» отражает лишь интересы китайской стороны, 
и в нем не заинтересованы и другие страны ареала Шелкового пути. В настоящее время Китай является крупнейшим торговым партнером Монголии и основным источником инвестиций. Однако, как отмечают китайские эксперты, обе страны сталкиваются с острой необходимостью оптимизации структуры подготовки и управления специализированными кадрами и налаживания научно-исследовательского сотрудничества.

Али Шабан, д.филол.н., профессор факультета иностранных языков и перевода Университета ал-Азхар (Египет, Каир); О.Г.Акинина, к.филол.н., доцент кафедры арабской филологии ИСАА МГУ имени М.В. Ломоносова (Россия, Москва) назвали свой совместный доклад: «Некоторые аспекты сотрудничества Египта и Монголии». Ученые отметили, что на современном этапе официальные отношения между Египтом и Монголией были установлены в 1964 году. В Каире в настоящее время находится единственное посольство Монголии на Африканском континенте. Между странами были подписаны различные соглашения о двустороннем сотрудничестве, в том числе и об увеличении числа монгольских студентов, проходящих обучение в Египте. В этой арабской стране проживает небольшое количество монгольских экспатриантов, в том числе этнических казахов, а также студенты из провинции Баян-Улгий, провинции Увс и Налайх Дюрег из Улан-Батора, которые изучают богословие в университете ал-Азхар - наиболее престижном мусульманском духовном университете.

Магистрант политологии университета Сакария А.Д. Тенизбаев (Турция) выступил на тему: «Геополитика Турции в среднеазиатских республиках, Восточном Туркестане и Монголии». Докладчик отметил, что распад Советского Союза серьезно повлиял на всю архитектуру международных отношений. Было много стран, которые начали претендовать на статус великой державы или, по крайней мере, на доминирующее место в определенном регионе мира. Среди них Турецкая Республика, которая также решила воспользоваться сложившейся ситуацией для увеличения своего веса на международной арене. Реализация этого амбициозного замысла предполагала разработку соответствующей внешнеполитической стратегии. Его основу составили три направления: турецкое евразийство, неопантюркизм и неоосманизм.

И.А. Игнатов, соискатель кафедры востоковедения МГИМО (Университет МИД РФ) выступил с докладом на тему: «Монгольская концепция «третьего соседа» и ее влияние на развитие российско-монгольских отношений», подчеркнув, что суть концепции «третьего соседа» заключается в том, что Монголия должна стремиться укреплять отношения не только со своими непосредственными соседями - Россией и Китаем - но и с развитыми демократическими государствами Запада и Востока (это и есть «третий сосед»), извлекая максимальную выгоду из сотрудничества со всеми зарубежными партнерами. При этом монголам следует избегать чрезмерной за- 
висимости от какой-либо одной державы либо группы государств и участия в коалициях, направленных против кого-либо из ее партнеров.

Подводя итоги второй сессии, модераторы отметили, что был представлен обширный пласт докладов, который затрагивал вопросы внешней политики Монголии, начиная с первой четверти XX века и до современности.

Также необходимо отметить, что были подготовлены доклады следующими участниками конференции:

T.А. Яшкова, д.п.н., профессор кафедры философии и социологии Академии труда и социальных отношений (Россия, Москва). Тема доклада: «Геополитический фактор: развитие отношений между Российской Федерацией и Монголией (современный аспект)». 3.С. Айдарбеков, д.филос.н., профессор Казахского университета Международных отношений и мировых языков имени Аблай хана (Казахстан, Алматы). Тема доклада: «Интеграция и регионализация на Евразийском пространстве: динамика развития казахско-монгольских отношений и перспективы». В.А. Сухарева, к.п.н., доцент кафедры международного сотрудничества Института управления и регионального развития РАНХиГС при Президенте РФ (Россия, Москва). Тема доклада: «Современная Монголия в мировых СМИ». Цзя Инь Кэ, глава Представительства Торгово-экономического Представительства Провинции Цзяньсу КНР в РФ и СНГ. Тема доклада: «Экономическое сотрудничество между Монголией и КНР». А.С. Донгак, к.филол.н., ведущий научный сотрудник Тувинского института гуманитарных и прикладных социально-экономических исследований (Россия, Республика Тыва, Кызыл). Тема доклада: «Генеральное консульство Монголии в Республике Тыва РФ (история образования и современность)». М.С. Алымкулов, д.филос.н., профессор Международного университета Кыргызстана (Кыргызстан, Бишкек). Тема доклада: «“Большая игра” Британской империи в Центральной Азии и Монголии и противостояние с Россией». О.П. Кобзева, д.и.н., профессор Национального университета имени Мирзо Улугбека (Узбекистан, Ташкент). Тема доклада: «Сотрудничество Монголии и Узбекистана на современном этапе». Г.А. Наматова-Керим, доцент Стамбульского Университета Айдын (Турция, Стамбул). Тема доклада: «Монголия - «новый азиатский экономический тигр». Э.С. Адилбекова, доцент Международного казахско-турецкого университета имени Ахмеда Ясави (Казахстан, Туркестан). Тема доклада: «Монголия, Тува и Алтай: “три кита” три монгольского шаманизма: религиозная толерантность, равноправие женщин, экология». С.А. Мукаш, магистр дипломатических наук, старший преподаватель Евразийского национального университета имени Л.Н. Гумилева (Казахстан, Нур-Султан). Тема доклада: «Политика Монголии и России в рамках $\mathrm{OOH».} \mathrm{В.В.} \mathrm{Штоль,} \mathrm{профессор} \mathrm{Дипломатической} \mathrm{академии}$ МИД РФ, главный редактор журнала «Обозреватель» (Россия, Москва). Тема доклада: «Боевое братство СССР и МНР в годы Второй мировой во- 
йны». И.В. Зайцев, д.и.н., профессор РАН, заместитель директора Государственного музея Востока (Россия, Москва). Тема доклада: «Особенности ислама в Монголии». Т.М. Махаматов, д.филос.н., профессор департамента гуманитарных наук Финансового университета при Правительстве Москвы (Россия, Москва). Тема доклада: «Историческое наследие и межкультурная коммуникация-основание евразийской цивилизации». Г.К. Уразалиева, к.филос.н., доцент Российского государственного гуманитарного университета (Россия, Москва). Тема доклада: «Российско-монгольские отношения: общие маркеры евразийской идентичности». Д.В. Сапрынская, н.с. ИСАА МГУ имени М.В. Ломоносова (Россия, Москва). Тема доклада: «Страны Центральной Азии в контексте российско-монгольских отношений». Р.И. Раимов, аспирант Института стран Азии и Африки МГУ имени М.В. Ломоносова. Тема доклада: «Роль Монгольской империи в динамике средневековой Мир-Системы». Д.С. Городилов, магистр востоковедения, атташе Третьего Департамента СНГ МИД РФ (Россия, Москва). Тема доклада: «Взаимодействие России и Монголии в области культуры и образования». Д.С. Сапарбекова, магистрант РАНХиГС (Россия, Москва). Тема доклада: «Сотрудничество Казахстана и Монголии в культурно-гуманитарной сфере». Ф.К. Тожидинов, аспирант ИСАА МГУ имени М.В. Ломоносова (Россия, Москва). Тема доклада: «Сотрудничество духовных управлений мусульман России и Монголии в XXI в.».

Итоги конференции подвела д.ист.н., профессор Ж.С. Сыздыкова, которая выразила слова благодарности модераторам, участникам и гостям конференции от имени Оргкомитета. 